\title{
BONDS IN THEIR RELATION TO CORPORATION FINANCE
}

\author{
By Frederick A. Cleveland, Ph.D., \\ Of Haskins \& Sells, New York.
}

Finance is defined as that branch of business which has to do with the getting and the spending of funds. A financial institution is a concern organized and conducted for the purpose of rendering service in funding operations, in exchange for which service it obtains an income. For example, the service for which a commercial bank is capitalized and equipped is to provide, in convenient form, the current funds by means of which business may be carried on; the service of a savings bank is to provide a safe and convenient form for the investment of funds saved-the form of the investment offered being an interest having credit account; the service of an underwriting syndicate is to insure the sale of issues of stock and bonds at an agreed rate, as a means of obtaining capital funds, etc. By corporation finance, it is assumed that reference is had to the funding operations of corporations.

\section{What Are Bonds?}

Bonds are one of the forms of instruments by the use of which funding operations are carried on. As an instrument, it is a contract entered into by the one desiring funds, with another having funds to invest. The contract is one of bargain and sale. There is no transaction which better illustrates the true character of a so-called loan than a bond issue. A so-called loan is the purchase of a promise to pay. The funds obtained on a loan is the amount for which a promisor is able to sell his contract for the future delivery of money. The amount that a promisor is able to obtain on sale of his contract for future delivery depends on the valuation placed on the promise by the investing public. Like all other sales, the price is agreed on only after a mental calculation as to whether that which is offered for sale is more valuable, to the one to which the offer is made, than the money in exchange for which it is proposed to sell. 
Credit contracts are of two essentially different forms, viz.: (1) credit accounts, and (2) promissory notes. A credit account is a contract for the future delivery of money, the evidence of which is a personal memorandum made by one or both parties to the transaction, or which is evidenced only in memory. A bank account, for example, is a contract made between a customer and a bank by the terms of which the bank promises to pay a certain amount of money on demand (usually without interest), the evidence of which is a memorandum made by the bank on a "pass book" which is handed to the customer. This account is ustually sold at par. A promissory. note is a formal contract, the written evidence of which specifies the principal amount to be paid, the date of payment, the rate of interest, the payor and the payee, the agreement covering not only the exact terms but also the exact form of the writing which shall represent these terms. The advantages of the two forms are apparent. The credit account is most frequently used for current or demand credit transactions, while the promissory note is the more common in transactions where a definite time and rate of interest are specified or where a definite form of security is given for payment. $A$ bond is a species of promissory note.

To understand properly the use of financial instruments, it is necessary to distinguish between current funds and capital funds. Current funds to a business man are his current means of purchase and of payment. It may be money or rights to draw, as on a bank. "Funds" when used in finance as a singular noun is a synonym of "cash." In business "cash" means all those forms of assets usually carried on the cash book. It includes all accounts with solvent banks, till cash and pocket money; sometimes it also includes postage stamps, and temporary advances or rights to draw on individuals to whom temporary advances have been made. Current funds is the cash intended to be used or held in reserve for the purpose of making current purchases, for meeting the amount of expenses, and for the payment of current liabilities. Capital funds is the cash which is procured or reserved for capital uses-i.e., for investment in the properties and equipment that is to be permanently or continuously used in the business. Both of these classes of cash are to be distinguished from the moneys or cash in possession, but which do not belong to the company, such as trust funds. Bonds are credit instruments commonly used to obtain capital funds. 
A bond is one of a series of promissory notes, usually of like tenor and amount, issued as evidence of a single credit agreement. Its serial issue arises from the character of the market and the purpose of its use. The purpose of a bond sale being to prucure funds for capitalization, the bond contract offered, consequently, is one which has a long time to run. Since the capital resources of a business are not to be sold or realized on for the purpose of meeting expenses and current liabilities, the funds obtained for capital use must be procured in such manner that the company will not be required to repay or return the amount contributed until this may be done without forcing a sale of the permanent properties and equipment. As a means of increasing competition among prospective purchasers, the total issue is divided into small notes of equal denominations, which, for convenience and for purposes of identification, are serially numbered. The total issue being large compared with the total assets of the obligor, and the time to run being long, a favorable valuation of corporate bonds may be obtained only by giving some form of security, each bond of the same issue having common rights and equal protection against default in payment of principal and interest when due.

\section{Principles Governing Bond Valuation}

Bonds are sold for cash, but why should a purchaser of bonds exchange money for a contract for the future delivery of money? The considerations which operate on the mind of the purchaser are essentially two: ( I) Rate of investment return, and (2) judgment as to whether the capital will become impaired. The rate of return is determined by a mathematical calculation based on two factors: (a) The price at which the bond is offered, and (b) the terms of the contract. A rate of return being offered which is attractive, favorable consideration involves two other judgments: (a) Judgment of the investor as to the ability of the promisor to obtain the amount promised at the time contracted for, and $(b)$ judgment as to the integrity of the promisor, $i$. e., on his willingness or disposition to fulfil his promise if he is able to obtain the amount promised. These two judgments with respect to the safety of his capital being favorable and the rate of return being satisfactory, the investor will buy. It is with respect to judgments as to the ability and integrity of the obligor that security has a direct 
bearing. In a bond issue the contract of security is the means whereby a favorable judgment is obtained in the valuation of the notes offered for sale.

\section{What Is Security to a Bond Issue?}

A contract of security is a collateral agreement by the terms of which certain property of the debtor is transferred to a trustee, to be held, and, in case of default in the credit contract, to be sold, the proceeds to be applied to the satisfaction of the debt; but in case of the credit obligation being met then the trust is ended and the title to the property so held reverts to the debit-beneficiary. ${ }^{1}$ Another form of contract of bond security is one pledging the paying power or money procuring ability of another as collateral to the credit promise. Such collateral promises are in the nature of endorsement or guarantee. The result of the contract of security is this : The value of the guarantee of payment or of the property pledged as security being considered sufficient to enable the creditor to obtain the amount of money promised in the credit contract, the investment is deemed amply protected. Through the collateral device known as security, both questions raised in the process of valuation are settled at the time of purchase: The question of willingness to pay ( $i$. e., of honesty) is determined by the wilingness of the debtor to enter into the collateral contract of security; the question as to paying ability is determined by the transfer of property which is estimated to be of sufficient value to enable the trustee, by sale, to obtain the money with which to meet the obligation. By investment companies, personal security is less highly valued than lien security for the reason that the personal ability and integrity of the endorser or guarantor may be subject to more of the shifting conditions, to more of the fortunes and misfortunes of business, and may be less readily controlled by the creditor than the properties assigned in trust, on which a lien is given. Personal property in the form of "collaterals," with power to compel the keeping up of an agreed margin, or real property, with ample margin of valuation and with provisions against waste and prior encumbrance such as taxes, receiver's cost, etc., when made the basis for valuation, places the creditor in a position to protect his invest-

${ }^{1}$ The creditor himself is frequently made trustee of the property of the debtor for the purpose of securing the obligation. 
ment as well as to insure an agreed rate of income. It is this quality which gives to bonds their place and importance in corporate finance.

\section{The Relative Importance of Bonds and Corporate Shares as In- vestments}

The relative importance of the two forms of capital issues of corporations-bonds and corporate shares-is to be found in the character of the contracts themselves. The corporation is a legally constituted artificial person endowed by legislative act with power to acquire and dispose of property. The shareholders are persons (or their successors) who have contributed funds (or other property) to the corporation in exchange for a right to participate in the general control of the company and to share in dividends declared out of profits. In other words, the shareholders are the proprietors of the corporation and have a right to income from their shares, contingent ( $I$ ) on net profits or surplus and (2) on the declaration of dividends out of net profits or surplus. Bondholders are persons (or their successors) who have contributed property or funds to the corporation in exchange for the corporation's promises to pay money. The bondholder as such does not stand in the relation of a proprietor; as creditor he has no rights of control over the company except to demand and enforce the payment of money in the amount and at the time promised. The bondholder's right to income is an absolute one, and, being a creditor, his claim is always prior to that of the proprietor.

But the bondinolder, through his collateral agreement, may also stand in proprietary relation, both to the property of the corporation and to the corporation itself. By taking a mortgage, or the obtaining of a pledge of collateral the bondholder (as trustee), or his representative, has a legal title to the property on which a lien is given to secure the payment of an issue of bonds. In case a real-estate mortgage is given, the corporation usually retains possession, but enjoys its equity subject to the terms and control of the grant. In case collaterals are pledged, the bondholder or his trustee obtains possession as well as the legal title to the property of the corporation deposited as security. But the conditions of the collateral agreement may go further; they may give to the bondholder, or his trustee, voting power. In other words, the stockholders may as(416) 
sign their rights to proprietary control over the corporation itself as a part of the security given for the payment of the money promised in the bond. Under a contract of personal security (endorsement and guarantee) only one of these proprietary relations may obtain. The nature of the security precludes the exercise of proprietary control over the property of the corporation; it may, however, give to the bondholder, or his trustee, the right to exercise voting power and to participate in the general direction of the corporation through control of the board.

\section{Motives to Bond Investment}

While such proprietary powers are possible, grants of voting power are seldom found in contracts of security, the only proprietorship insisted on being that which has reference to the property pledged. And this does not interfere with its use (except as against impairment) so long as interest is regularly paid and the principal obligation is met when due. This fact suggests the motive to bond investments. Generally speaking, the bond investor is not a person who wishes to charge himself with the duties and responsibilities of proprietorship in those concerns to which he contributes capital. One who has built up a large and profitable business may wish to retire. To accomplish this end, and at the same time make it possible for a successor to capitalize the business to advantage, he may sell to a corporation taking a large portion of the purchase price in first mortgage bonds. Again, an investment may be desired for an infant or a person incompetent to manage and control. For such a one an investment which secures the principal and guarantees a regular income is most attractive. A foreigner may find that competition for local issues has reduced the rate to a point lower than he cares to accept for this use of his capital. He turns to distant, perhaps to colonial enterprise, where a larger income is promised. Not being in a position to participate in control, he seeks a preferred and secured claim. He sells his capital, surrenders control and accepts a promise to pay with an assignment of property which he believes to be adequate to protect him from loss, leaving to the proprietors of the corporation the possibilities of still larger return in dividends on their corporate shares. Investment companies generally have such an absentee and inactive constituency. Savings banks and court trustees, for example, are not so much interested 
1n an extraordinary investment return as they are in providing an assured income sufficient to enable them to meet their responsibilities to depositors, or to beneficiaries under supervision of the courts. Such institutions are usually compelled by law to restrict their investments to prescribed issues. For this purpose bonds of the highest security and preferment are specified. The recent insurance laws of the state of New York definitely forbid investments in corporate shares and in issties of bonds secured by corporate shares deposited in trust. This legislation, however, did not emanate from a desire to strengthen the security for the investment so much as from a desire to preclude the use by the trustees of large cumulations of trust funds for purposes of corporate control.

\section{Unsecured Bonds}

A large portion of the bonds currently traded in are unsecured. Aside from those of doubtful or inferior character sold by misrepresentation or taken in settlement of existing claims, they are of two general classes: (I) the short time issues of private corporations, or (2) the issues of public corporations, such as federal, state or municipal governments. The first of these two classes of unsecured bonds appeals to much the same constituency as does onename commercial paper. The second class of unsecured bonds is considered among the best of long time investments. Each rests on the same kind of investment judgment-the valuation of the unsecured paying ability and business integrity of the debtor. A private corporation which has a large floating debt, small net earnings, and doubtful surplus, would have difficulty in selling unsecured issues except at such a sacrifice as to make them an object of speculative buying; a private corporation whose officers and trustees had not honorably treated its creditors in the past, whatever its paying and income producing ability, would likewise have difficulty in disposing of an unsecured issue. A government, strangulated by debt, that had reached its revenue producing limit, that had suffered its credit issues to go by default, especially if it had refused to pay obligations purchased in good faith, would be unable to find a market for bonds except as specific security is given which is considered adequate protection to the investor. The reason that unsecured public bonds are preferred as investments is that the in(4I8) 
tegrity of the government issuing them is unquestioned, and the debt-paying ability is unimpaired.

Legally, a government has the power to tax limited only by its charter or constitution. Economically, a government's revenue producing power is limited to the surplus profits of private business, for any attempt to levy which goes beyond the surplus net profits of business will leave no inducement for private persons to engage in business pursuits and will drive the capital already invested to jurisdictions where conditions are more favorable. In most of the American states and municipalities the legal debt and tax limit is placed far below the economic debt and tax limit. The result is that practically the only questions to be considered are political integrity and authority. It is seldom necessary to inquire into the ability of American states or municipalities to pay. As a consequence, their unsecured issues, as a class, are considered better investments, from the viewpoint of protection to principal, than the secured issues of private corporations. Many foreign states are not so fortunately situated, and to make their bonds marketable it is necessary that some specific property or form of revenue be pledged as security.

\section{The Uses of Bonds and Corporate Shares in Current Funding Operations}

Aside from their investment character to persons who do not care actively to participate in the management of business affairs (or who are incapable of such participation), bonds and corporate shares have an important use in current funding operations. Without regard to income or the character of business in which he may be engaged, one who may have made investments of this character, may go to bank, and, by depositing the securities under a collateral loan agreement, may procure current funds at a favorable loan rate to an amount approximating the market value of these securities. It is not an uncommon practice for merchants as well as investors to use a part of their working capital in the purchase of securities to operate as an invested surplus. When their stock in trade is low, and when the quarterly or semi-annual buying season occurs, these investments are employed as collateral to loans with which wholesale bills may be discounted. The same practice is common to com- 
panies which have used a part of their capital to purchase corporate shares for purposes of control. The use of collaterals as a means of obtaining current funds is especially prevalent in financial districts where such funds are available for loans "on call."

Under our national banking system it is the practice of out-oftown banks to loan a large part of their money reserves to "reserve city banks." These loans are at the rate of from two to three per cent. Being subject to "call" by the out-of-town banks, the central city banks in turn offer loans to their customers "on call" secured by collateral. These call rates are often as low as one-half of one per cent, and the average rate is between two and three per cent. Not being required under the banking law to carry a money reserve of more than twenty-five per cent of the amount borrowed from other banks, the reserve city banks are able to loan to customers three times as much of their own credit as the amount loaned to them by other banks; as a consequence, there is a margin of profit to the city banks in call loans even at a lower rate than they themselves must pay for the money obtained from their banking correspondents. The constituency desiring call loans, however, is largely a speculating constituency, and for this reason the great speculating centers are the places where out-of-town banks find the best rates for loaning their surplus money reserves. So prevalent has the practice become in what is known as financial centers that, in these places, the business of banking has degenerated from the old time occupation of loaning on the business credit of merchants and manufacturers after a careful consideration of the profits or prosperity of their undertaking, and has become a species of pawnbroking-the pawns or pledges offered being stocks and bonds instead of jewelry and other personal effects. These collateral loan transactions being left largely to "loan clerks," the attention of discretionary officers is turned to the obtaining of loans from out-of-town banks, and to such operations as have come to be known as "high finance." When application is made for a personal loan no question may be raised as to the sanity of the venture in which the current funds are to be used, to the profitableness or income producing ability of the applicant, but query comes from the loan clerk "what is your collateral?" If the collateral offered is regularly traded in, the "ticker" establishes the basis of credit; if not regularly traded in, then the issue must relate itself to transactions or corporations in which the bank 
has a funding interest or to issues which are duly accredited by an officer. Such a practice has in large measure removed our great commercial banks from support to a mercantile and manufacturing constituency and definitely attached them to the stock market; it has deprived the country at large of that steadying influence which comes with the exercise of financial wisdom based upon commercial and industrial judgment; the condition of credit and the current funding power of the nation has become closely related to the speculative changes and manipulated movements reflected in Lombard and Wall Streets. Without a change in industrial and mercantile conditions bank credits may be suddenly expanded or reduced to the extent of hundreds of millions of dollars.

Another use of bonds in current funding operations has been incorporated into our national banking law, viz.: the investment of a large part of the banking capital of the nation in government bonds which may be pledged at par to the Treasury as collateral for issues of bank notes. Since no interest is charged on the notes received by the banks on these collateral deposits and no provision is made for the exercise of discretion on the part of the government as to when note issues may be obtained on such pledges, it is to the immediate advantage of the bank to keep its capital investments pledged, and to use the bank notes for the purchase of commercial paper, thus adding to the income received from the government on the bonds, the interest obtained on the commercial paper purchased by use of the notes. The "reserve deposit" practice has contributed materially to unsettle credit conditions, by stimulating speculation, the tying up of capital in bond collaterals, impairs the ability of the banks to meet them. This practice is largely responsible for what is known as "inelasticity" in bank credit. It has permitted the government to borrow at a low rate, but has very seriously crippled the commerce and industry of the country.

\section{The Increasing Demand for Bonds.as Inzestments}

In relation to corporations seeking capital, bonds are most important instruments of capitalization. In relation to persons and institutions having capital to invest they afford an element of safety which does not attach to many other forms of investment. The increasing demand for bonds closely relates itself to present social and industrial conditions. During the last two decades capitali- 
zation and management of enterprises have become so highly centralized that a large proportion of the people have become wage earners. The greater. economies of production and distribution incident to co-operative activity under corporate organization has made it more profitable for the small merchant and small producer to take employment from a corporation than to operate an independent business. In the past, as small proprietors, those who were engaged in business had an ever present opportunity for investment in the increased capitalization of their own business, while those who had earned and saved might join in a partnership already established or start a new business. The increased economy of large production has in great measure destroyed these investment opportunities. The small proprietorship is at a disadvantage. The employee of the great corporation is placed in the peculiar position; he has increased his income and his possible savings by becoming a wage earner, but he is deprived of opportunities for investing his increased savings in properties or business within his control. Opportunity for profitable investment is being gradually reduced to corporate issues, as to the value of which the possessors of these incomes have little opportunity to judge except as these valuations are reflected in the market. At the same time the market is so largely affected by speculations that the quotations reflect manipulation and financial impulse rather than sound consideration of the producing and earning capacity of corporations whose issues are traded in. The tendency of the time, therefore, is either to speculate, which usually results in loss to the so-called outsider; or turn to the credit of certain trustees and investment companies. Among the most popular of these is the savings bank account. The savings bank is in a position to give careful consideration to the investment value of corporate issues of bonds and shares. These issues are held as an invested fund for the collateral security of the interest bearing accounts sold to savers. Another form of investment which seems to be growing in popularity is the collateral trust bond of companies which syndicates purchase and sell issues against these collaterals in denominations which are within the reach of the small buyer. This form of bond investment, under proper regulation, is capable of affording protection and at the same time of supplying the fast-growing demand for the safe employment of small 
surpluses as a means of providing income to the provident. Endowment policies of life insurance companies is another form of cooperative investment which combines safety with protection against the loss of life.

\section{Dangers to Investors in the Capital Obligations of Corporations}

The underlying bonds of a prosperous corporation and the obligations of investment companies which are secured by such issues are the safest investments that may be made. Corporate shares of companies which have paid dividends for a period of years and whose financial statements show large surplus as well as continued net profits are also attractive to those who have capital to invest. These issues, however, are not without their dangers. With all the protection thrown about secured bondholders in practice, it has been found that they have suffered loss. These losses have come from one of two causes, viz.: (I) Overvaluation of the security at the time of the bond purchase, or (2) impairment of the value of the security after the bond purchase.

If the security be in the nature of endorsement or guarantee, then it is the ultimate debt paying ability of the payor and endorser or guarantor that must be appraised. If this becomes impaired before the bonds become due, it is seldom that the bondholder has any recourse. The value of personal credit and personal security may also become impaired by the negligence of the bondholder himself. The officers of the company may be permitted to tuse the property and credit of the corporation for their own benefit, having entered into a collateral contract, the endorser or guarantor has certain rights which must be observed unless these rights are specifically named.

If the security be in the nature of a conditional transfer of property, the valuation of the bondholder at the time of the purchase may be made on a wrong basis; or, from indifference or inability to procure the necessary information, he may sleep on his rights, allowing the property to depreciate or become wasted. Property pledged as security for collateral trust bonds may usually he valued on the basis of current market quotations, and in case the trust agreement provides for the maintaining of a margin, protection against depreciation may be afforded by substitution or supplementary collateral deposits. But even with provisions 
of this kind, the company issuing the bonds may not have the additional collaterals available, and any proceeding to enforce the trust agreement may cause greater loss to the investor than the impairment which would follow if no action were taken.

In bond issues secured by real-estate or by the capital resources and equipment of the issuing company, the value of the property pledged usually depends on its earning power. Such properties may be overestimated at the time the bonds are purchased by reason of failure to obtain accurate information. Too frequently bonds are issued and sold without investigation or appraisement of property; too frequently issues are purchased by persons who buy because a particular banking house is underwriting the issue, or, what is still more fallacious, because a particular company is trustee under the mortgage. After the issue has been disposed of, bondholders frequently rest content with watching the market instead of demanding and obtaining information as to whether the property is being wasted through neglect, through failure to repair, through default in meeting requirements as to reserves for depreciation and sinking funds, or through the declaration of dividends out of capital and the gradual distribution of the available resources of the company to stockholders under color of false statements showing net profits and surplus.

Looking toward the purpose of bond issues and corporate shares in their relation to the capitalization of modern business undertakings, it is of unceasing importance that every safeguard be thrown around investments of this kind. In the industrial régime such as that which has developed within the last two decades, protection to the investor must come through some form of control over corporate management which will guarantee the integrity of financial statements, and hold corporate officers and trustees to strict account to those whose capital has been contributed to the enterprise. Legally the corporation lends itself to the highest form of control and its officers too may be held to strictest account. In theory of law, no one in proprietary relation to the company, either as stockholder or as secured creditor, may transact any of its business. Both the property and the management are placed in the hands of a group of trustees called "officers." Again the officers themselves are appointed and controlled by a second group of trustees called "directors." Neither of these groups of 
trustees may legally use any of the property or conduct the business of the corporation for their own benefit, and both are strictly accountable. The protection which comes through the law of trusteeship is complete. The weakness of the position of the investor before the courts has been not lack of law, but lack of evidence. As a matter of proof, or enforcement of rights, there have been two essential elements lacking: ( I) Evidence as to the character of discretion used in the management of this company's affairs by the officers, the corrective for which is found in the election and appointment of representatives, and (2) eviclence as to breach of trust, the corrective for which is found in the courts. In both cases, when the evidence has been obtainable, it has come too late or has been too uncertain to be effective.

\section{Methods by which Dangers to Investors may be Overcome}

Whether the investment be in the form of bonds or corporate shares, whether the bonds held be secured by personal guarantees or by liens on specific properties, the protection of the investor relates itself directly to corporate managment - to the ability and good faith of those to whom the affairs of the corporation have been intrusted. As before suggested, the nature of the corporation is such that neither may its property be held nor its affairs be managed by those who have contributed its capital; these must be intrusted to agents-to the control of officers and directors. Questions of successful management and fidelity of trust must be determined by the holders of bonds and shares from reports rendered to them. The records of the company from which these reports are made are kept by the officers-by those who are to give an account of their stewardship. Too often the only requirement made of the officer or trustee is that interest shall be met and a satisfactory rate of dividends be declared and paid.

For effective legislative requirements, looking toward the protection of bondholders and shareholders, by providing the means for obtaining evidence of the character of discretion used, and as to fidelity of stewardship, we must look to Great Britain. In America, such protection as is afforded comes largely as a voluntary act of officers or trustees who have accepted corporate responsibilities. Under the companies' acts of Great Britain, the stockholders are made responsible for bringing their own agents to account and pro- 
tecting their own investment interests. At their regular meetings they are required to appoint a disinterested person to audit the accounts of the company, and to certify to the condition of its affairs, the auditor so selected being made both civilly and criminally liable for the truth or falsity of financial statements. Should the stockholders fail to elect, an auditor is appointed by the government.

In the United States, even when audits are made, the auditor is appointed by the officer or agent whose stewardship is to be reported on. The employment is therefore subject to such conditions and restrictions as may be imposed. Necessarily, the report of the auditor is rendered to the ones with whom the engagement is made. If, therefore, any comment or suggestion may appear in the report which is in the nature of criticism, such comment or suggestion may be withheld from bondholder and shareholder. A balance sheet may be certified to as correct and an income and expense account may be properly stated without disclosing facts by way of comment which are of serious moment to the investment interests.

Effort has been made to cure the evils of irresponsible corporate management, and to protect the investor from loss by the institution of public offices of corporate control. Officers of corporations are required to make sworn statements to these public agencies, and public examiners are appointed to investigate corporate resources and liabilities; but at best, these agencies cannot serve the same purpose and give the same protection as an audit which goes into questions of official discretion and efficiency as well as of fidelity, and which is reported direct to the investor instead of being filed away as a secret document in a department of state, where no action may be taken unless bankruptcy is threatened or evidence is procured of breach of trust. Adequate protection to the investor, against official incompetence, against high salaries to officials, and high prices to contractors, against depreciation of properties, against improper charges of betterments to accounts of repairs and replacements resulting in a hidden or inflated surplus, may be had only through an exhaustive audit and direct report to those who hold the proprietary interests in the company and who may administer correctives in the choice of officers and trustees to direct the affairs of the corporation without resort to laborious, and often times ruin- 
ous resort to the courts. Such a law as that which has been found so effective in England would do more to correct corporate abuses and protect the integrity of corporate issues, than all the inquisitorial and restrictive measures that may be enacted. The public officer may be used effectively as a police power, but investors should be given the means whereby they may protect themselves. Such a regulation should be incorporated in every law as a condition precedent to exercise of delegated powers. 